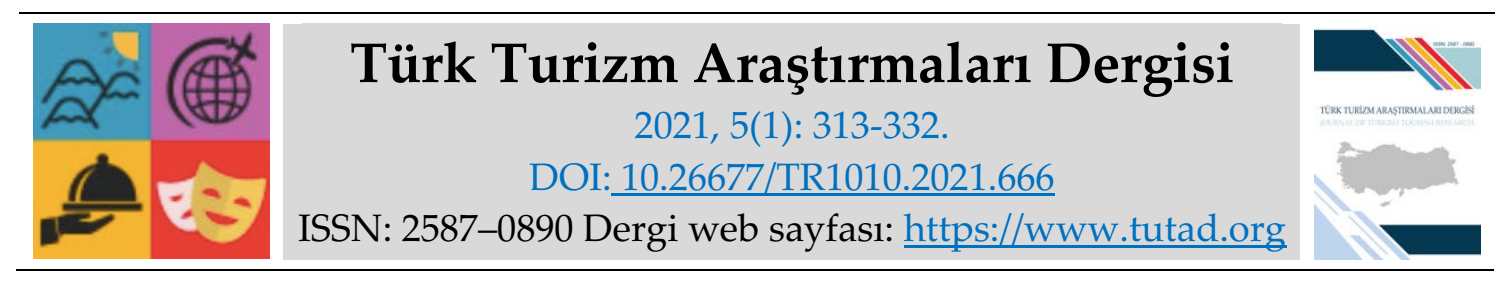

ARASTTIRMA MAKALESI

\title{
Ilgaz Dağı Milli Parkı'nda Yer Alan Köylerin Kırsal Turizm Algısı
}

Arş. Gör. Gürkan ÇALIŞKAN, Kastamonu Üniversitesi, Turizm Fakültesi, Kastamonu, e-posta: gcaliskan@kastamonu.edu.tr ORCID: https://orcid.org/0000-0003-2596-153X

Doç. Dr. Canan TANRISEVER, Kastamonu Üniversitesi Turizm Fakültesi, Kastamonu, e-posta: ctanrisever@kastamonu.edu.tr ORCID: https://orcid.org/0000-0003-4747-5903

Dr. Öğr. Üyesi İrfan MISIRLI, Kastamonu Üniversitesi, Turizm Fakültesi, Kastamonu, e-posta: imisirli@kastamonu.edu.tr ORCID: https://orcid.org/0000-0001-9400-005X

Öz

Araştırma alanı olarak Ilgaz Dağı Milli Parkı sınırları içerisinde yer alan 12 köy belirlenmiştir. Çalışmanın amacı Ilgaz Dağı Milli Parkı içerisinde yer alan köylerin kırsal turizm potansiyelini sosyo-kültürel yönleriyle değerlendirmektir. Bu kapsamda çalışmada, Ilgaz Dağı Milli Parkı sınırlarında yer alan 12 köy muhtarı ile yapılan odak grup görüşmeleri aracılığıyla veriler toplanmış ve elde edilen verilere MAXQDA programı ile analiz edilerek haritalandırılmıştır. Muhtarların köy halkına yönelik görüşleri incelendiğinde, yerel halkın kırsal turizme olumlu baktığı, ancak kırsal turizmin gerçekleştirilmesinde en büyük kısıtların, yerel ve ulusal ölçekte mali kaynak desteği, mesleki eğitim ve istihdam eksikliği olduğu tespit edilmiştir.

Anahtar Kelimeler: Kırsal Turizm, Ilgaz Dağı Mili Parkı, Ilgaz Köyleri, MAXQDA

Makale Gönderme Tarihi: 22.09.2020

Makale Kabul Tarihi: 06.03.2021

\section{Önerilen Atıf:}

Çalışkan, G., Tanrısever, C. ve Mısırlı, İ. (2021). Ilgaz Dağı Milli Parkı'nda Yer Alan Köylerin Kırsal Turizm Algısı, Türk Turizm Araştırmaları Dergisi, 5(1): 313-332.

(C) 2021 Türk Turizm Araştırmaları Dergisi. 


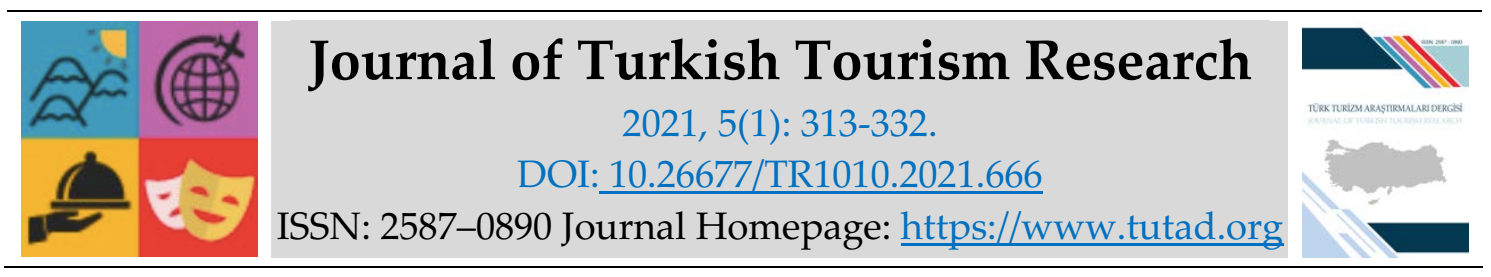

\title{
$\underline{\text { RESEARCH PAPER }}$
}

\section{Rural Tourism Perception of the Villages in The Ilgaz Mountain National Park}

Research Assistant Gürkan ÇALIŞKAN, Kastamonu University, Faculty of Tourism, Kastamonu, e-mail: gcaliskan@kastamonu.edu.tr ORCID: https://orcid.org/0000-0003-2596-153X

Assistant Prof. Dr. Canan TANRISEVER, Kastamonu University, Faculty of Tourism, Kastamonu, e-mail: ctanrisever@kastamonu.edu.tr

ORCID: https://orcid.org/0000-0003-4747-5903

Associate Prof. Dr. İrfan MISIRLI, Kastamonu University, Faculty of Tourism, Kastamonu, email: imisirli@kastamonu.edu.tr

ORCID: https://orcid.org/0000-0001-9400-005X

\begin{abstract}
12 villages within the borders of Ilgaz Mountain National Park were determined as research area. The aim of the study is to evaluate the rural tourism potential of the villages located in Ilgaz Mountain National Park in terms of socio-cultural aspects. In this context, data were collected through focus group interviews with 12 village headmen in Ilgaz Mountain National Park, and the obtained data were analyzed and mapped with the MAXQDA program. As a result of the opinions of the headmen about the village people, it has been determined that the local people have a positive view on rural tourism, but the biggest constraints in the realization of rural tourism are financial support at local and national scale, vocational training and lack of employment.
\end{abstract}

Keywords: Rural, Rural Tourism, Ilgaz Mountain National Park, Ilgaz Villages, MAXQDA.

Received: 22.09 .2020

Accepted: 06.03.2021

\section{Suggested Citation:}

Çalışkan, G., Tanrısever, C. and Mısırlı, İ. (2021). Rural Tourism Perception of the Villages in The Ilgaz Mountain National Park, Journal of Turkish Tourism Research, 5(1): 313-332.

(c) 2021 Türk Turizm Araştırmaları Dergisi. 


\section{Gíriş}

Kastamonu 2023 Turizm Stratejisi'nde ve Turizm Şurası kararlarında ismi doğa turizmi ile anılan bir kenttir. Bu kapsamda Kastamonu Üniversitesi de "Tabiat Turizmi ve Ormancllı" alanında ihtisaslaşmıştır. Kastamonu'nun resmi ziyaretçi kaydı tutulan ve en önemli doğa turizmi merkezlerinden biri olan Ilgaz Dağı kış turizmi ile bilinir olsa da kış ayları dışında doğaseverler için önemli bir destinasyon olmaya adaydır. Günümüzde turizm talebi kültür bazlı ve yavaş gelişim gösteren doğa kaynaklarına doğru yönelmektedir. Doğal güzelliklere, kültür değerlerine sahip olan ve geleneksel hayatı yansıtan turizm çeşitlerine olan ilgi artmaya devam etmektedir. Bu nedenle, yerel etkinlikler, doğal güzellikler, tarım ürünleri, yöresel ögeleri ve sosyo-kültürel ögeleri barındıran kırsal turizm destinasyonları turistler için önemli bir çekicilik unsurları olarak görülmektedir (Özgürel, 2015).

Kırsal turizm; kırsal coğrafi bölgede mevcut aktivitelerin, doğal ve kültürel ürünlerin çekiciliği ile meydana gelen ve pek çok farklı boyutu içerisinde bulunduran oldukça karmaşık bir kavramdır (Uçar, Çeken ve Ökten, 2010). Kırsal kavramını, Türk Dil Kurumu (TDK) daha az bireyin barındığı, çoğunlukla kır konumunda olan yöre olarak tanımlamaktadır [TDK]. Diğer bir tanıma göre; nüfusun görece daha az olduğu, ekonominin tarım kaynaklı olduğu, gelenek ve göreneklerin etkisinin süregeldiği, kentsel bölgelere nispeten, sosyal öğeler açısından gelişmemiş bölgeler olarak ifade edilmektedir [TKIB]. Dünyada "Kırsal Turizm" olgusu ile başlıca temaların; çiftlik turizmi, yayla turizmi, tarımsal turizm, ekoturizm, av turizmi, mağara turizmi ve doğa sporları gibi farklı başlıklarda toplandığı görülmektedir.

Kırsal turizm, kıyı turizmine ek bir seçenek olarak ortaya çıkan, günümüzde daha çok kıyı turizminin tamamlayıcısı ve birçok turizm etkinliğini de bünyesinde barındıran turizm çeşididir. Kırsala olan ilgi yeni bir olgu değildir. Endüstrinin gelişmesi ve çalışma koşullarında meydana gelen stres, endüstriyel şehirlerdeki kalabalık, çevresel kirlilik vb. unsurlar sebebiyle bireyler kaçış, uzaklaşma arayışına girerek doğaya yönelim göstermektedirler. Kırsal alanlar doğa ile iç içe bulunma olanağı sunarak bir nevi fiziksel ve ruhsal dinlenme alanları olarak görülmektedir. Kırsal turizm, turistlere kırsal bölgelerde konakladıkları yöreye özgü deneyimler katan, yerel halklarda ise kültürel ve doğal çevrenin korunmasına yönelik faaliyetlerin farklı boyutları üzerine çalışan turizmdir (Bouchon ve Rawat, 2016). Günümüzde bireylerin deniz-kum-güneş üçlüsüne yönelik seyahatler yerine şehir hayatı ile beraber, tek düze yaşam, doğal ürünlere olan ilgi, kırsal yaşama duyulan merak ve özlemin artışı ile kırsal turizme yönelim günümüzde artış göstermektedir. Kırsal bölgelerdeki doğayı, farklı kültürleri, yöresel etkinlikleri görmek ya da deneyimlemek gibi faaliyetler, tüm paydaşlarda meydana getirdiği etkiler sebebiyle sosyal, kültürel ve ekonomik kalkınmada önemli bir unsur olarak nitelendirilmektedir (Yemenoğlu, Dalgın ve Çeken, 2013). Bu noktada kırsal turizm, ekonomik ve sosyal kalkınma ve yenilenmeyi sağlamanın bir aracı olduğu düşünülmektedir. Özellikle, kırsal alanlarda ve geleneksel tarım üretiminin düşüş gösterdiği destinasyonlarda etkili bir gelir ve istihdam kaynağı olarak yaygın bir şekilde tanıtılmaktadır. Kırsal turizmin içerisinde doğal, sosyal ve kültürel faaliyetler bulunmaktadır. Yöreye ait olan değerler ve çekicilikler turizm faaliyet içerisinde değerlendirilebilir. Bunlar; köy dügünleri, yöreye ait olan ürünler, yemekler, el sanatları ve yöresel etkinliklerdir. Yöreye ait olan değer ve etkinliklerin her biri yörenin tanıtılması ve ekonominin gelişmesi için önemli bir aracıdır (Avcıkurt ve Köroğlu, 2011). Kırsal turizm faaliyetleri sonucunda gelen turist sayısının artarak, yörenin imajına olumlu yönde etki sağlaması, istihdam yaratılması, kadın ve yerel halk içerisinde dezavantajlı bireylerin üretime katılması, kırdan kente göçün önüne geçilmesi ve yöreye özgü tarımsal ve sosyo-kültürel öğelerin korunarak ziyaretçilere sunulması sağlanmaktadır. Kırsal halkın, turizm ve doğal çevre farkındalığının oluşması ve kültürel miras değerlerinin bilincine varılması ile yörenin yaşam standardını yükseltmek için de katkı sağlamaktadır. Sosyal, kültürel, ekonomik ve doğal çevreye 
yönelik katkılar çerçevesinde yöre halkını, yerel etkinlikleri sürdürme hususunda teşvik etmektedir.

\section{LITERATÜR TARAMASI}

Kırsal turizminin en önemli bileşenlerinden biri yerel etkinliklerdir. Bu etkinlikler yöreye olan ilgiyi arttırmakla birlikte, turistik çekicilik oluşturmada yeterli değildir. Kırsal turizm, günümüzde nispeten daha az kitlesel etkinliklere odaklanan ve özellikle yiyecek ve içeceklere olan ilgiyi ve yerel bir destinasyonu yeniden keşfetme isteği doğrultusunda, kültürel miraslara ve geleneksel yaşama daha fazla odaklanan bir boyuta ulaşmaktadır. Nitekim kırsal turizm, kırsal alanların kimliğinde önemli bir alan yaratmaktadır. Kırsal turizmin bir tarım bileşiği olduğu doğrulanarak, ekolojik ürünler, kültürel miraslar, bölgesel olanaklar, ekonomik, sosyokültürel çeşitli ögeleri içeren, eğitim, çevre ve eğlence aktivitelerinin her birini kapsamaktadır (Lee ve Kim, 2010). Belletti, Berti, (2011) ise: kimileri kırsal turizmi tarım ve tarım ürünlerinin işlenmesi ile sınırlı olarak tanımlama eğilimindedirler, buna karşın, ekolojik alanlar deneyimlenirken bir yandan kırsal alanlarda ve köylerde mevcut kültürel ve sanatsal kaynaklar kullanılmaktadır. Ayrıca, sadece bulunduğu yere özgü kırsal turizm, bir kırsal alanın ülkeden ülkeye neyi kapsadığı kavramına dair farklılıklar üzerine problemlere yol açmaktadır. Bu bağlamda kırsal turizm, yalnız bir deneyim değil aynı zamanda yapıldığı dönemdir (Lane, 1994). Diğer taraftan, ekonomi dinamikleri ve tarım politikalarının evrimi karşısında değişime ve gerilemeye mahkum olacak arazilerin kullanım olanaklarından kaynaklanmaktadır (Belletti, 2010). Birçok ülkede, kırsal turizm için önemli boyutta teşvik, destek ve bazı durumlarda halktan ve özel sekterden doğrudan mali yardım sağlamaktadır (Fleischer ve Pizam, 1997). Hall ve Jenkins (1998)'e göre böyle bir söz konusu destekler sürpriz değildir. Son otuz yılda, birçok bölgede kırsal ekonomi düşerek önemli bir kriz geçirmektedir. Geleneksel tarımda istihdam ve gelir düzeyleri kısır bir ekonomi yaratarak, sosyo-ekonomik problemler meydana getirmektedir. Özellikle kişi başına düşen kırsal gelirler ortalamaları düşmektedir. Yüksek işsizlik seviyelerine rağmen daha genç, daha iyi eğitimli kırsal kesim bireylerinin kentlere göç etmesine ve kırsal dokunun yitirilmesine sebebiyet vermektedir (OECD, 1993).

Kastamonu ili kırsal turizm için önemli bir potansiyel olarak değerlendirilmiştir. Şen ve Erkan Buğday (2015) çalışmalarında Kastamonu ilinde iki milli park, dört tabiat anıtı, dört yaban hayatı geliştirme sahası, üç tabiat parkı, iki muhafaza ormanı, 22 gen koruma ormanı ve 19 mesire alanı bulunduğunu ifade ederek Kastamonu ilindeki zenginliği belirtmişlerdir. Oktay, İşlek ve Yaşar (2016) ve Zengin, Koç ve Ulama (2019) çalışmalarında Kastamonu ilinin zengin doğa turizmi kaynakları olmasına rağmen, bu kaynaklardan yeterince faydalanılamadığını belirtmişlerdir. Akkuş ve Akkuş (2019) çalışmalarında Kastamonu ilinin ilçe arz kaynak envanterleri üzerinde durmuşlardır. Bu bağlamda ilde öne çıkan turizm türlerinin de tabiat turizmi alt türleri ve doğa sporları olduğu görülmektedir. Batı Karadeniz Bölgesi'nde yer alan Ilgaz Dağı Milli Parkı da kırsal turizm potansiyeli barındıran bir alan olarak görülmektedir. Yeşiltaş, Çeken ve Öztürk (2009) çalışmalarında Ilgaz Dağı Milli Parkı'nın özellikle dağcılık, trekking ve av turizmine uygun olduğunu belirtmişlerdir. Göktuğ ve Arpa (2015) çalışmalarında bölgede yapılabilecek etkinlikler arasında kış turizmi, fauna gözlemi, foto safari, dağ bisikleti ve kamp gibi etkinlikleri ifade etmişlerdir. Akkuş (2019) çalışmasında Ilgaz Dağı'nın potansiyelini irdelemiştir. Bu bağlamda Ilgaz Dağı'nın önemli bir kış turizmi potansiyeli olduğu vurgulanmıştır.

Ilgaz Dağı Milli Parkı'nda yer alan kış turizmine yönelik yapılan tesisler dışında bahar ve yaz aylarında doğaseverleri ağırlayacak mekânlar ve kamp alanları yetersizdir. Bu kapsamda, Ilgaz Dağı Milli Parkı sınırlarında yer alan köyler kırsal turizm için ne kadar uygun? sorusundan hareketle yola çıkılan bu çalışmada öncelikle köylere gidilip gözlem yapılmıştır. Ev 
pansiyonculuğuna uygun evler tespit edilmiştir. Bu kapsamda, çalışmada Ilgaz Dağı Milli Parkı sınırları içinde kalan köylerinin kırsal turizm potansiyeli ve kırsal turizm algılarını ortaya koymak amaçlanmaktadır. Bu çalışma, özellikle destinasyon planlaması gerçekleştirecek olan yerel yönetim ve özel sektördeki karar verici ve uygulayıcıların bütüncül bir yaklaşım izlemesine yardımcı olarak pratiğe katkı sağlayacaktır.

\section{Ilgaz Dağı Milli Parkı}

Ilgaz Dağı, Batı Karadeniz Bölgesinin bölgesinin iç kesimlerinde, Kastamonu Havzası ile Devrez Vadisi arasında batı-doğu yönünde, yaklaşık $160 \mathrm{~km}$ 'lik uzunluktadır. Dağın yüksek noktasındaki zirvesi Büyükhacat tepesi 2587 m, ardında yer alan Küçükhacat tepesi ise 2546 m yüksekliğe sahiptir (T.C.I.K.). Nitekim, Milli park alanında, jeolojik ve jeomorfolojik oluşumlar, göz alıcı orman alanları, kayak pisti ile sınırları oluşturan dereler bulunmaktadır. Zengin bitki örtüsü, yaban hayatı ve endemik bitkiler barındırması nedeniyle Ilgaz Dağı 02/06/1976 yılında Milli Park ilan edilmiştir (Kuter, 2008). Dağ, Kastamonu'ya 40 km, Çankırı'ya 80 km, Ankara'ya $200 \mathrm{~km}$, İstanbul'a ise $553 \mathrm{~km}$ uzaklıktadır. IDMP mevcut bitki örtüsü, yabani yaşam, coğrafi konumu ve çeşitlilik gösteren doğal peyzaj ögeleri noktasında büyük bir önem taşımaktadır (Kuter, 2008). Sinop ve Kastamonu illerini Ankara'ya bağlayan D-765 karayolu ile Orta ve Doğu Karadeniz Bölgesi ile Doğu Anadolu Bölgesinde bulunan illeri İstanbul'a bağlayan E-80 karayolu üzerinde bulunan Ilgaz ilçesi, Çankırı il merkezine 50 km, Kastamonu il merkezine 60 km, Ankara il merkezine $185 \mathrm{~km}$ uzaklıktadır. İlçenin yüz ölçümü 784 km² olup, İlçe merkezinin denizden yüksekliği 920 metredir (T.C. Ilgaz Kaymakamlığı, 2017).

\section{YÖNTEM}

Çalışmada veri elde etmek amacıyla gözlem, doküman analizi ve Ilgaz Dağı Milli Parkı sınırları içerisinde yer alan köy muhtarları ile 2019 yılında odak grup görüşmesi gerçekleştirilmiştir. Yarı yapılandırılmış soru formu aracılığıyla yüz yüze gerçekleştirilen görüşmeler ses kayıt cihazı kullanılarak kayıt altına alınmıştır. Bu kapsamda 12 köy muhtarı ile görüşme tamamlanmıştır. 12 köy muhtarı ile yapılan odak grup görüşmelerinde 6 tane sorudan oluşan demografik veriler, kültürel peyzaj, konaklama, alt yapı hizmetleri, tanıtım ve pazarlama ve doğal peyzaj kategorilerinden oluşan 33 adet köylerine ait soru yöneltilmiştir. Muhtarların kırsal turizm algısına yönelik 11 açı uçlu soru MAXQDA programında analiz edilmiştir.

Verilerin analizinde sorulara verilen yanıtlar temalara ayrılarak gruplandırılmış ve karşılaştırmalı olarak analizleri yapılarak bulgular elde edilmiştir. Kodlanan veriler program içerisindeki "Görsel Araçlar" bölümünde yer alan "MAXMaps" kullanılarak haritalandırılmıştır. Çalışmada içerik analizi yöntemi uygulanmıştır. İçerik analizinde, elde edilen veriler irdelenerek kategorilere ayrılır ve temalandırılır (White ve Marsh , 2006: 30). Veriler içerisinde tekrar edilen veya vurgulanan ifadelerin kodları çıartılır. Çalışmada elde edilen verilerden toplam $149 \mathrm{kod}$ çıkartılmıştır. Çalışma kapsamında belirlenen kodlar şu şekildedir: 


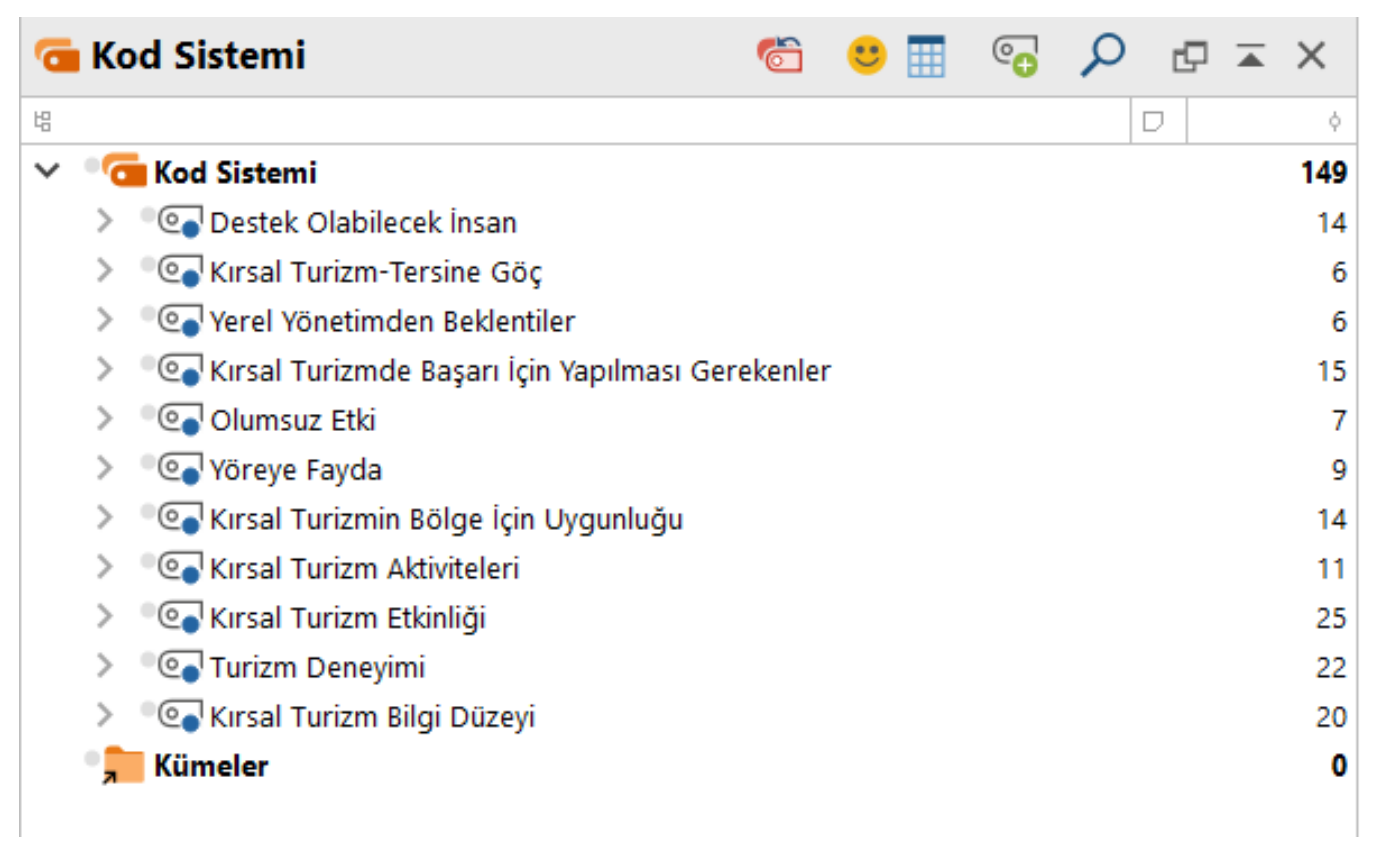

Şekil 1. Kod Sistemi

Araştırmada Batı Karadeniz Bölgesinde yer alan Ilgaz Dağı Milli Parkı incelenmiştir. Çalışmada, öncelikle alanyazın taraması yapılmıştır. Tarama sonucunda rekreasyon etkinlikleri, bölgenin mevcut turizm durumu ve konaklama tesisleri ile ilgili veriler elde edilmiştir. Bölgenin doğal, kültürel ve demografik yapısı değerleri irdelenerek, kırsal turizm potansiyeli tespit edilmiştir. Yörenin kırsal turizm potansiyeli hakkında alanyazın çalışmalarından elde edilen verilerle doğrudan bölgede yapılan inceleme ve gözlem sonuçları birleştirilerek bir bütünlük sağlanmıştır.

Katılımcılara yöneltilmek üzere yarı yapılandırılmış görüşme formu hazırlanmıştır. Görüşme formunun hazırlanma sürecinde uzman kişilerin görüşleri alınmış ve ifadelerin açık ve anlaşılır olduğu anlaşılmıştır. Katılımcılara belli bir düzen içerisinde sıralanmış 11 adet açık uçlu soru yöneltilmiştir. Katılımcılara, genel destinasyon bilgilerinin ardından, kırsal turizm potansiyele dair spesifik bilgilere yönelik bir sıra izlenmiştir.

\section{BULGULAR}

Bulgular demografik ve katılımcıların bakış açılarını ölçmeye yönelik açık uçlu sorular olmak üzere iki ayrı başlık altında değerlendirilmiştir.

\section{Katılımcılara Dair Bulgular}

Odak grup görüşmesine dâhil edilen Ilgaz Dağı Milli Parkı sınırları içerisinde görev yapan 12 muhtara öncelikle ilk altı soruda kendilerini tanıtmaları istenmiştir. Ek olarak, kaç yıldır köylerinde ikamet ettikleri ve köye dışarıdan gelen veya yerleşen kişi mevcudiyetine dair bilgiler sorulmuştur. Katılımcıların yaş aralıkları 36 ile 65 ve üzeri arasında değişiklik göstermektedir. 3 katılımcı lise, 3 katılımcı ortaokul, 6 katılımcı ilkokul mezunudur.

\section{Katılımcıların Kırsal Turizm Olgusu Bakış Açılarına Dair Bulgular}

Ilgaz Dağı Milli Parkı sınırları içinde bulunan köylerin muhtarları ile kırsal turizmin bölgeye yapacağı olumlu ve olumsuz etkiler değerlendirilmiştir. Kırsal turizm olumlu etkileri olarak; istihdam artışı, göçün azalması, yeni kültürlerin öğrenilmesi, ekonomik olanakların ve 
bilinirliğin artması ifadelerine yer verilmiştir. Negatif etki olarak köy nüfusunun sosyo-kültürel olarak turizmden negatif etkilenebileceği belirtilmiştir. Tüm bu görüşlere istinaden analiz sonucunda, Ilgaz Dağı Milli Parkı sınırları içerisinde yer alan muhtarların kırsal turizme verdikleri yanıtlar, "ekonomik fayda", "istihdam artışı" ve "kültürel etkileşim" temaları altında birleştirilmiştir. Şekil 2'de katılımcıların, kırsal turizm olgusuna dair bulgular ve temalandırma gösterilmektedir.

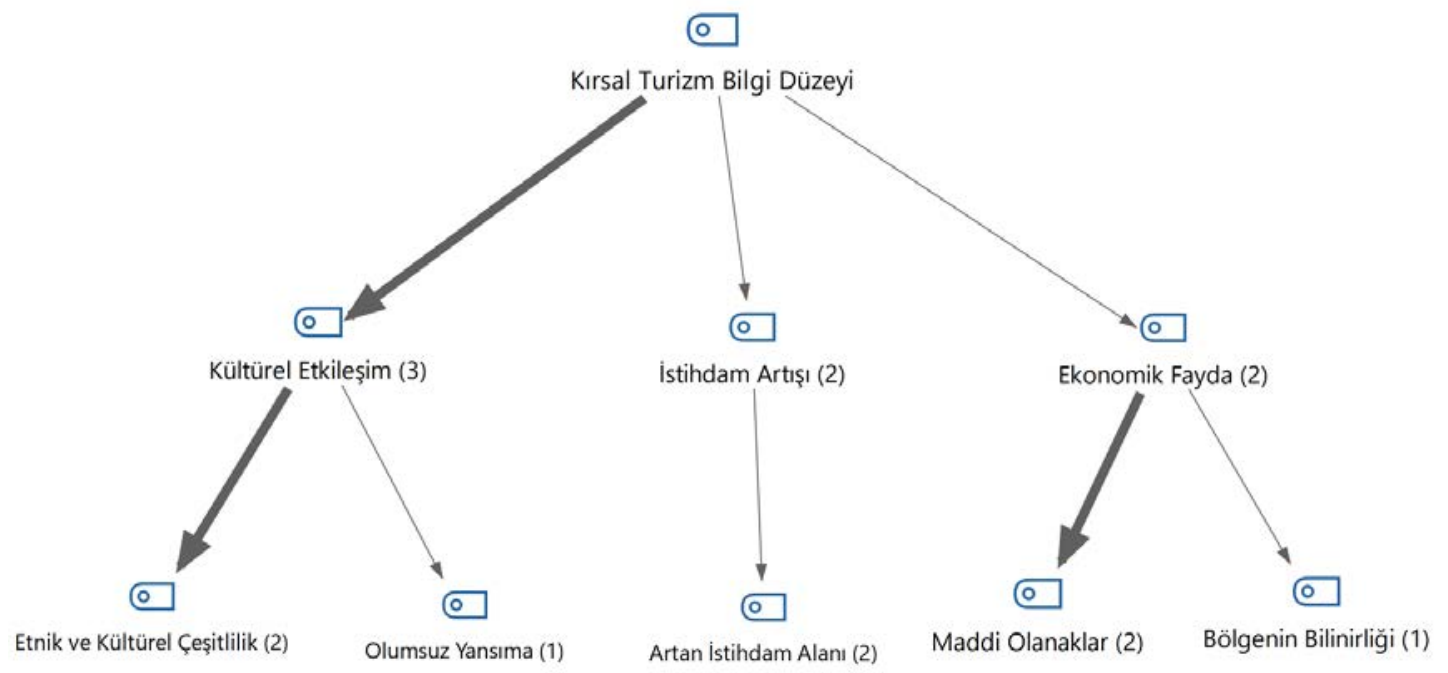

Şekil 2. Katılımcıların Kırsal Turizm Olgusu Bakış Açılarına Dair Bulgular

Katılımcların kırsal turizme yönelik genel olarak olumlu bir izlenime sahip olduğu ve kırsal turizmin kendi bölgelerinde yaratacağı fırsatların bilincinde oldukları gözlemlenmektedir. Katılımcılardan sadece biri kültürel etkileşim teması altında endişesini dile getirmiştir. Katılımcı endişesini aşağıdaki şekliyle ifade etmiştir:

"Köyde yaşayanlara etnik ve kültürel faydaları olacaktır. Kültürel kaynaşma açısından da faydası vardır. Fakat farklı kültürlerle kaynaşmanın olumsuz yansımaları da olabilir."

Katılımclardan ikisi kırsal turizmi istihdam artışı için bir fırsat olarak gördüklerini, bu fırsat ile köyden kente göçün de azalacağını ifade etmişlerdir.

\section{Milli Park Sınırları İçerisinde Köylerin Kırsal Turizm Deneyimini Değerlendirmeye Dair Bulgular}

Ilgaz Dağı Milli Parkı sınırları içerisinde yer alan köy muhtarlarına bölgenin kırsal turizm potansiyeli ve önceki turizm deneyimlerine ilişkin sorular yöneltilmiştir. Kırsal turizm potansiyeli yerel halk açısından, festivaller, inanç etkinlikleri, el sanatları, bisiklet veya atlı doğa sporları olarak değerlendirilmiştir. Tüm bu görüşlere istinaden analiz sonucunda, Ilgaz Dağı Milli Parkı sınırları içerisinde yer alan muhtarların daha önce turizme katılıma dair verdikleri yanitlar, "kültürel etkinlikler", "geleneksel el sanatları" ve "kamp ve doğa sporları" temaları altında birleştirilmiştir. Şekil 3' de katılımcıların, turizm potansiyelini değerlendirmelerine dair bulgular ve temalandırma gösterilmektedir. 


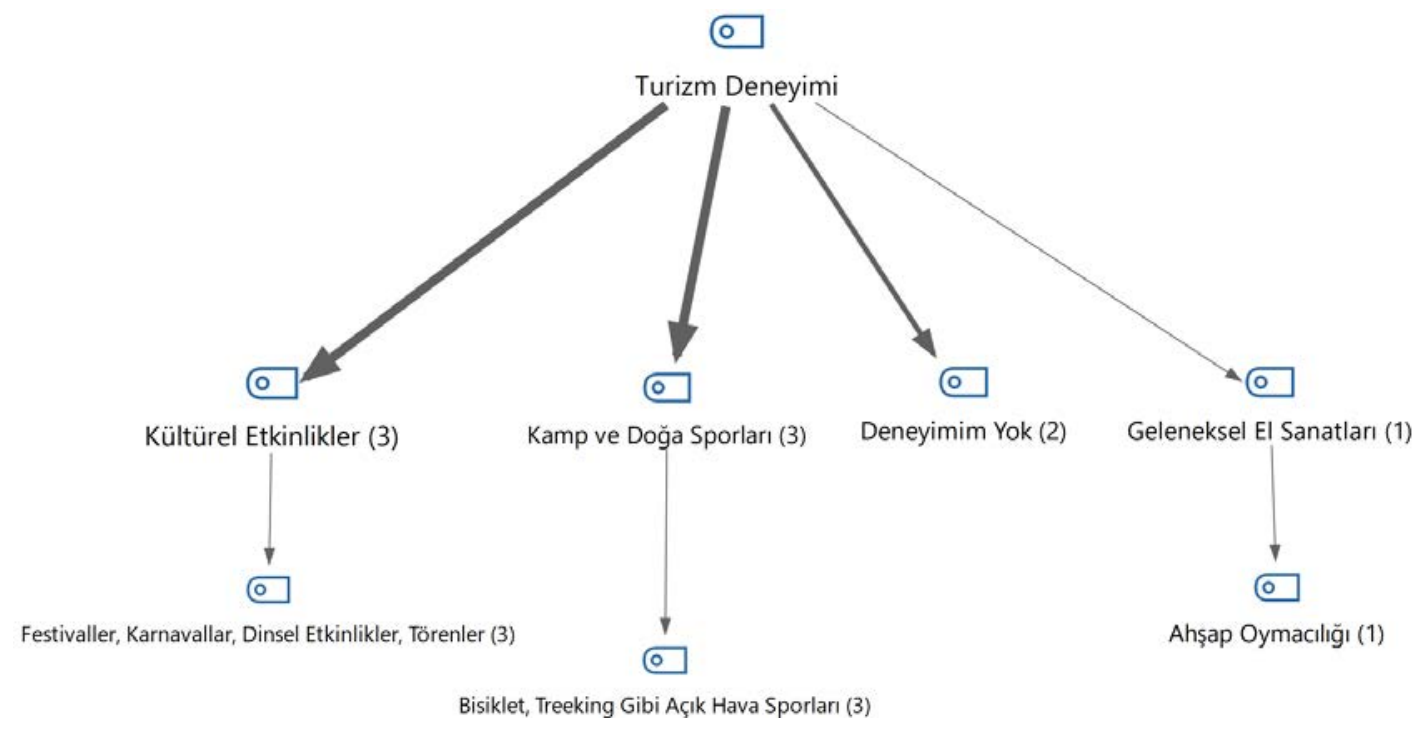

Şekil 3. Katılımcıların Turizm Potansiyelini Değerlendirmeye Dair Bulgular

Katılımcıların genelinde geçmiş turizm deneyimleri olduğunu anlaşılmaktadır. Bu deneyimleri kamp, doğa sporları ve kültürel etkinlikler oluşturmaktadır.

\section{Milli Park Sınırları İçerisinde Köylerin Kırsal Turizm Katılımlarını Değerlendirmeye Dair Bulgular}

Ilgaz Dağı Milli Parkı sınırları içerisinde yer alan köy muhtarları ile kırsal turizm etkinliklerine daha önce dâhil olmalarına ilişkin “Daha önce bir kırsal turizm etkinliğine katıldınız mı?" sorusu sorulmuştur. Kırsal turizme katılım yerel halk açısından, kar ve çim kayağı, tırmanış, doğa yürüyüşleri, geleneksel yayla evi konaklama ve ağırlama hizmetleri, yaban hayvanları avcıllı̆̆ başlıklarında değerlendirilmiştir. Tüm bu yanıtlar, "dă̆ ve kışsporları", "yayla turizmi" ve "av turizmi" temaları altında birleştirilmiştir. Şekil 4'de katılımcıların, kırsal turizm katılım potansiyelini değerlendirmelerine dair bulgular ve temalandırma gösterilmektedir.

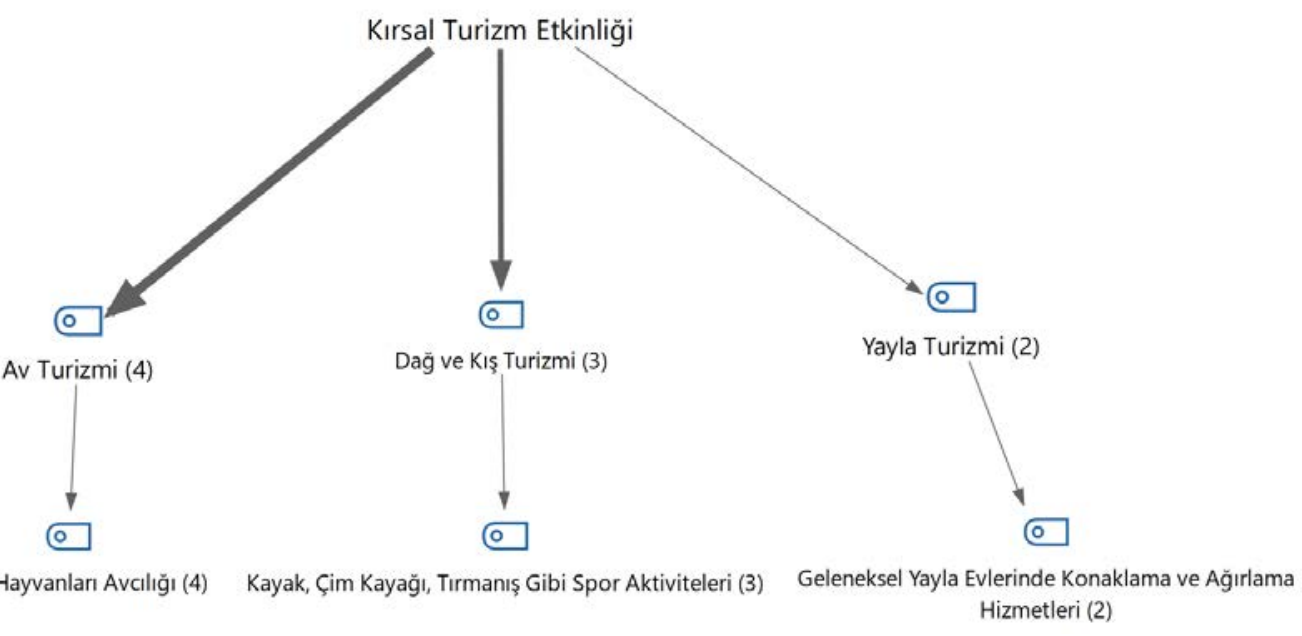

Şekil 4. Kırsal Turizm Katılım Potansiyelini Değerlendirmelerine Dair Bulgular 
Katılımcların kırsal turizm etkinliklerine katılım sağladıkları ve bölgede yürütülebilecek turizm faaliyetlerinin farkında oldukları gözlemlenmektedir.

\section{Milli Park Sınırları İçerisinde Köylerin Kırsal Turizm Etkinlik Çeşitliliklerinin Bilinirliğine Dair Bulgular}

Ilgaz Dağı Milli Parkı sınırları içerisinde yer alan köy muhtarlarına kırsal turizm dâhilinde hangi aktivitelerin kapsadığına ilişkin "Kırsal turizmin hangi turizm aktivitelerini içerdiğini düşünüyorsunuz?" sorusu sorulmuştur. Kırsal turizm, yerel halk açısından, kar ve çim kayağı, tırmanış, doğa yürüyüşleri, geleneksel yayla evi konaklama ve ağırlama hizmetleri ve at ile yapılan doğa gezileri olarak değerlendirilmiştir. Tüm bu görüşlere istinaden analiz sonucunda, Ilgaz Dağı Milli Parkı sınırları içerisinde yer alan muhtarların daha önce kırsal turizm etkinliklerinin ne tür aktiviteleri kapsadığına dair verdikleri yanıtlar, "binicilik", "kış ve dăg sporları" ve "yayla turizmi" temaları altında birleştirilmiştir. Şekil 5'de katılımcıların, kırsal turizm etkinliklerini değerlendirmelerine dair bulgular ve temalandırma gösterilmektedir.

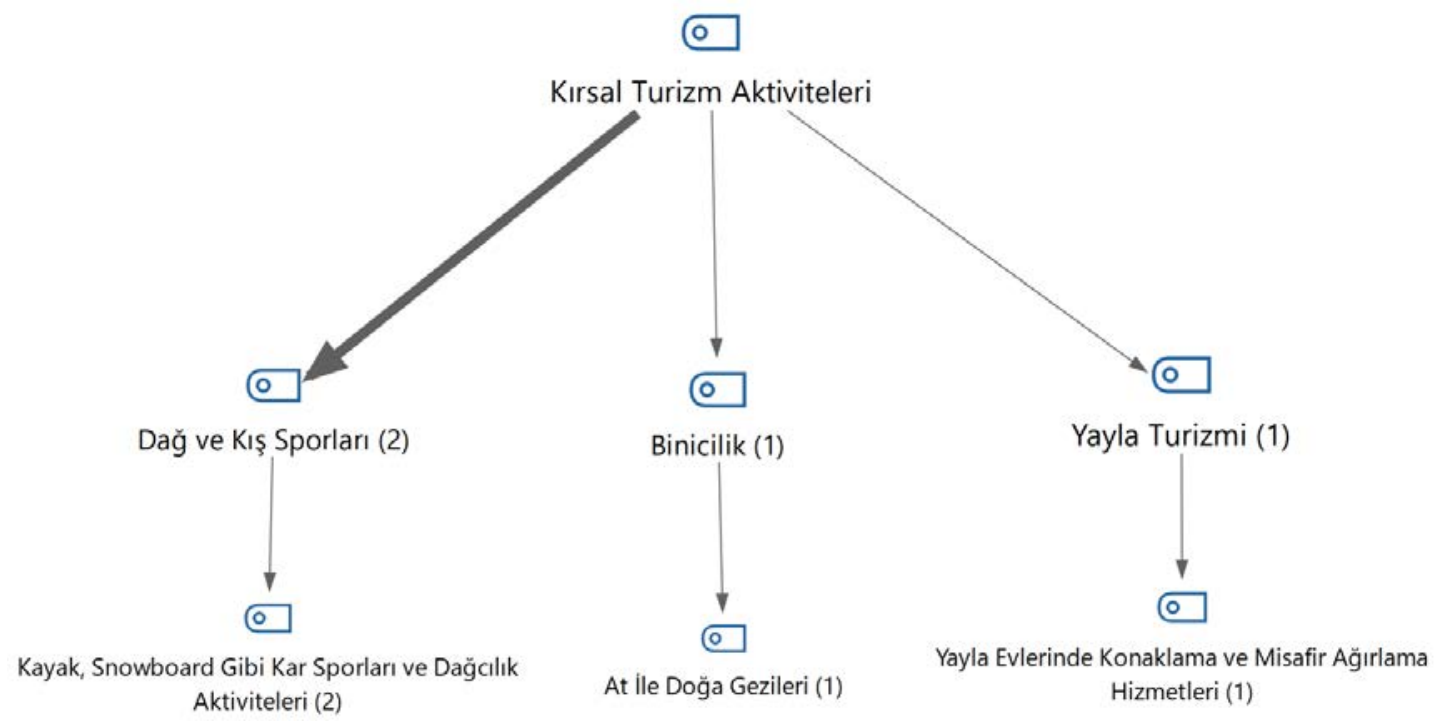

Şekil 5. Kırsal Turizm Etkinlik Çeşitliliklerinin Bilinirliğine Dair Bulgular.

Katılımcların kırsal turizm aktivitelerini yayla turizmi, dağ ve kış sporları ve binicilik olmak üzere üç ana başlık altında değerlendirdikleri görülmektedir.

\section{Milli Park Sınırları İçerisinde Köylerin Kırsal Turizmin Bölge için Uygunluğuna Dair Bulgular}

Ilgaz Dağı Milli Parkı sınırları içerisinde yer alan köy muhtarlarına "Kırsal turizm için yaşadığınız coğrafyanın uygun olduğu görüşünde misiniz?" sorusu sorulmuştur. Kırsal turizmin bölge açısından uygun olduğu ve bölgenin öne çıkan özellikleri arasında; tarihi değerler, düğün, kına gecesi gibi geleneksel etkinlikler, keşkek gibi yöresel yemekler, temiz hava, ormanlar ve yöresel el sanatları başlıkları belirtilmiştir. Tüm bu görüşler ışığında yapılan analiz sonucunda, Ilgaz Dağı Milli Parkı sınırları içerisinde yer alan muhtarların kırsal turizmin bölge için uygunluğuna dair verdikleri yantlar, "kültürel çekicilikler" ve "doğal güzellikler" ve "el 
sanatları" temaları altında birleştirilmiştir. Şekil 6'da katılımcıların, kırsal turizmin bölge için uygunluğuna dair bulgular ve temalandırma gösterilmektedir.

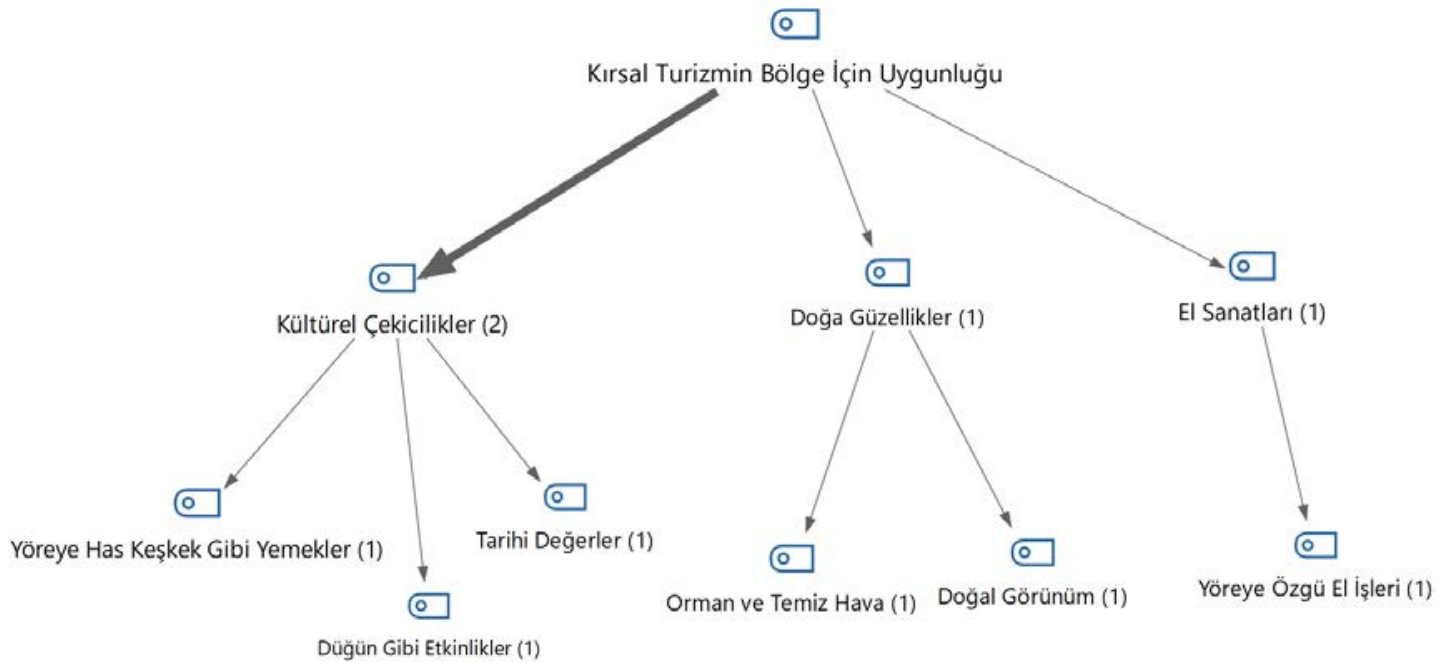

Şekil 6. Kırsal Turizmin Bölge için Uygunluğuna Dair Bulgular

Katılımcılar yörenin kırsal turizm için uygun olduğunu ve çekicilik unsurları barındırdıklarını ifade etmişlerdir. Kültürel çekicilikler, doğal güzellikler ve el sanatları bölgelerin önemli değerleri olarak görülmektedir. Katılımcılardan ikisi kültürel çekicilikleri ön plana çıkarmışlardır. Bu katılımcılardan ilki yörenin yemeklerinin bir değer olduğu görüşündedir:

"Yörenin kültürel tarihi ve geleneklerini deneyimleyip, kültürümüzün bir ögesi olan yemeklerimizin kırsal turizm kitlesi için önemli olduğu görü̧̈ündeyim."

Bir diğer katılımcı ise geleneksel kıyafetleri ön plana çıkarmıştır:

"Yöremizin kına geceleri ve düğ̈̈nlerde giyilen kıyafetlerimiz kırsal turizm katılımcıları için ilgi çekicidir."

\section{Milli Park Sınırları İçerisinde Köylerin Kırsal Turizmin Bölgeye Sağlayacağı Katkılara Dair Bulgular}

Ilgaz Dağı Milli Parkı sınırları içerisinde yer alan köy muhtarlarına "Kırsal turizmin yörenize ne gibi fayda sağlayacağı görüşündesiniz?" sorusu sorulmuştur. Kırsal turizmin bölgeye sağlayacağı katkılar, maddi kaynak artışı, yeni iş sahaları ve koruma altına alınma başlıklarında değerlendirilmiştir. Tüm bu görüşlere istinaden yapılan analiz sonucunda, Ilgaz Dağı Milli Parkı sınırları içerisinde yer alan muhtarların kırsal turizmin bölgeye sağlayacağı katkılara dair verdikleri yanıtlar, "ekonomik fayda", "istihdam artışı" ve "sürdürülebilir turizm gelişimi" temaları altında birleştirilmiştir. Şekil 7'de katılımcıların, kırsal turizmin bölgeye sağlayacağı katkılara dair bulgular ve temalandırma gösterilmektedir. 


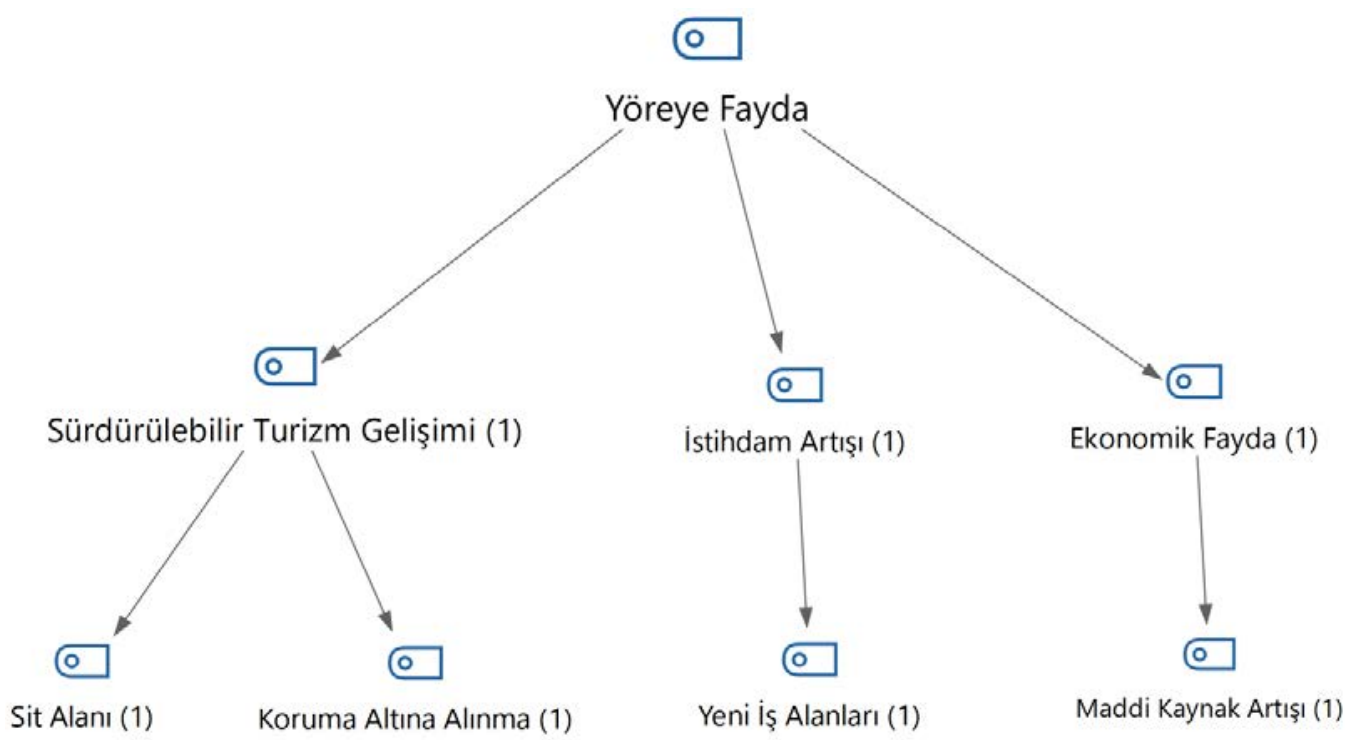

Şekil 7. Kırsal Turizmin Bölgeye Sağlayacağı Katkılara Dair Bulgular.

\section{Milli Park Sınırları İçerisinde Köylerin Kırsal Turizmin Bölgeye Getireceği Ön Görülen Zararlara Dair Bulgular}

Ilgaz Dağı Milli Parkı sınırları içerisinde yer alan köy muhtarlarına "Kırsal turizmin sizce yörenize negatif etkisi olur mu?" sorusu sorulmuştur. Kırsal turizmin bölgeye getireceği ön görülen zararlar, yeni kültürlerden yöre halkının olumsuz yönde etkilenmesi, kalabalık ve doğa ile ilgili problemler başlıklarında değerlendirilmiştir. Tüm bu görüşlere istinaden analiz sonucunda, Ilgaz Dağı Milli Parkı sınırları içerisinde yer alan muhtarların kırsal turizmin yöreye getireceği ön görülen zararlar, "kültürel yozlaşma" ve "taşıma kapasitesinin aşımı" temaları altında birleştirilmiştir. Şekil 8'de katılımcıların, kırsal turizmin bölgeye getireceği zararlara dair bulgular ve temalandırma gösterilmektedir.

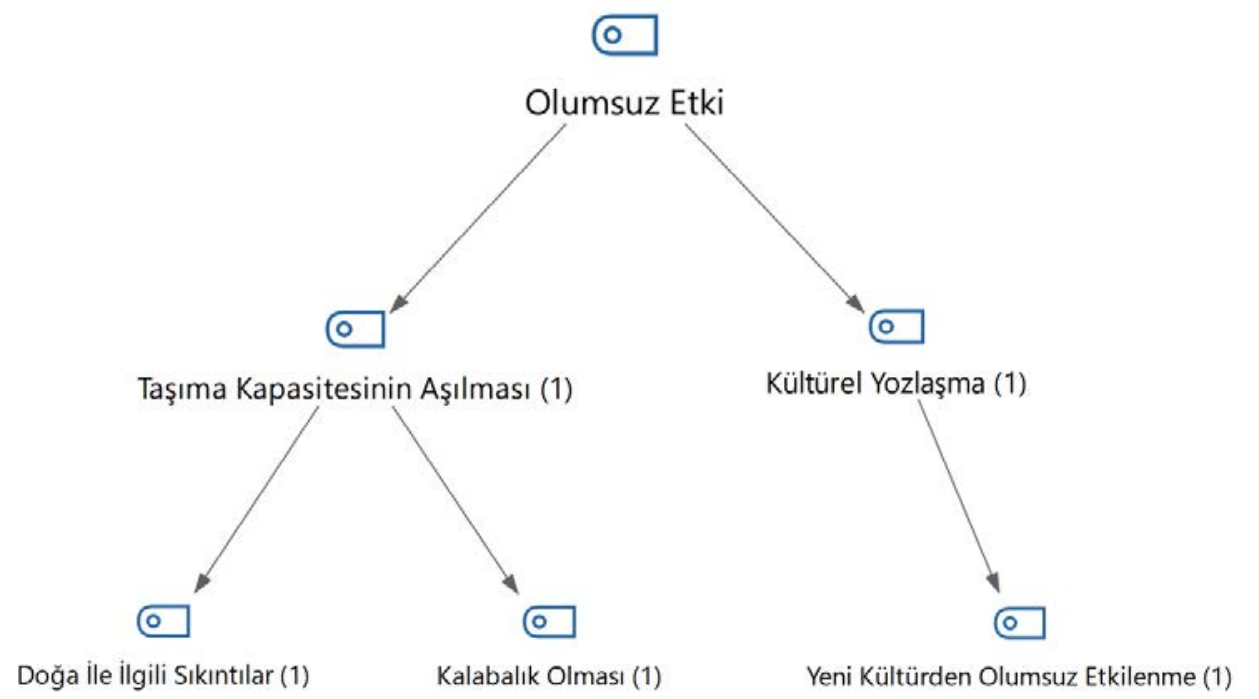

Şekil 8. Köylerin Kırsal Turizmin Bölgeye Getireceği Ön Görülen Zararlara Dair Bulgular. 
Katılımcılar, kültürel yozlaşma ve taşıma kapasitesinin aşılması konusunda fikirlerini belirtmişlerdir. Taşıma kapasitesinin yetersiz kalabileceğini dile getiren katılımcı düşüncelerini şu şekilde yansıtmıştır:

"Kırsal bölgelerde konaklama için mevcut evlerin yetersiz olabileceği ve kırsal turistlerin bakir doğayı bozabileceğini düşünmekteyim."

\section{Milli Park Sınırları İçerisinde Köylerin Kırsal Turizmin Uygulanabilmesi İçin Ön Görülere Dair Bulgular}

Ilgaz Dağı Milli Parkı sınırları içerisinde yer alan köy muhtarlarına "Kırsal turizmin başarılı bir şekilde uygulanabilmesi için sizce neler yapılması gerekir?" sorusu sorulmuştur. Kırsal turizmin uygulanabilmesi için, devletten maddi destek ve turizm alanında çalışacak yöre halkı için gerekli donanım ve eğitimler başlıklarında verilen cevaplar değerlendirilmiştir. Tüm bu görüşlere istinaden analiz sonucunda, Ilgaz Dağı Milli Parkı sınırları içerisinde yer alan muhtarların kırsal turizmin yörede uygulanabilmesi için gerekli ön görüler, "devlet teşviki" ve "mesleki eğitim" temaları altında birleştirilmiştir. Şekil 9' da katılımcıların, kırsal turizmin yörede uygulanabilmesi için ön görülere dair bulgular ve temalandırma gösterilmektedir.

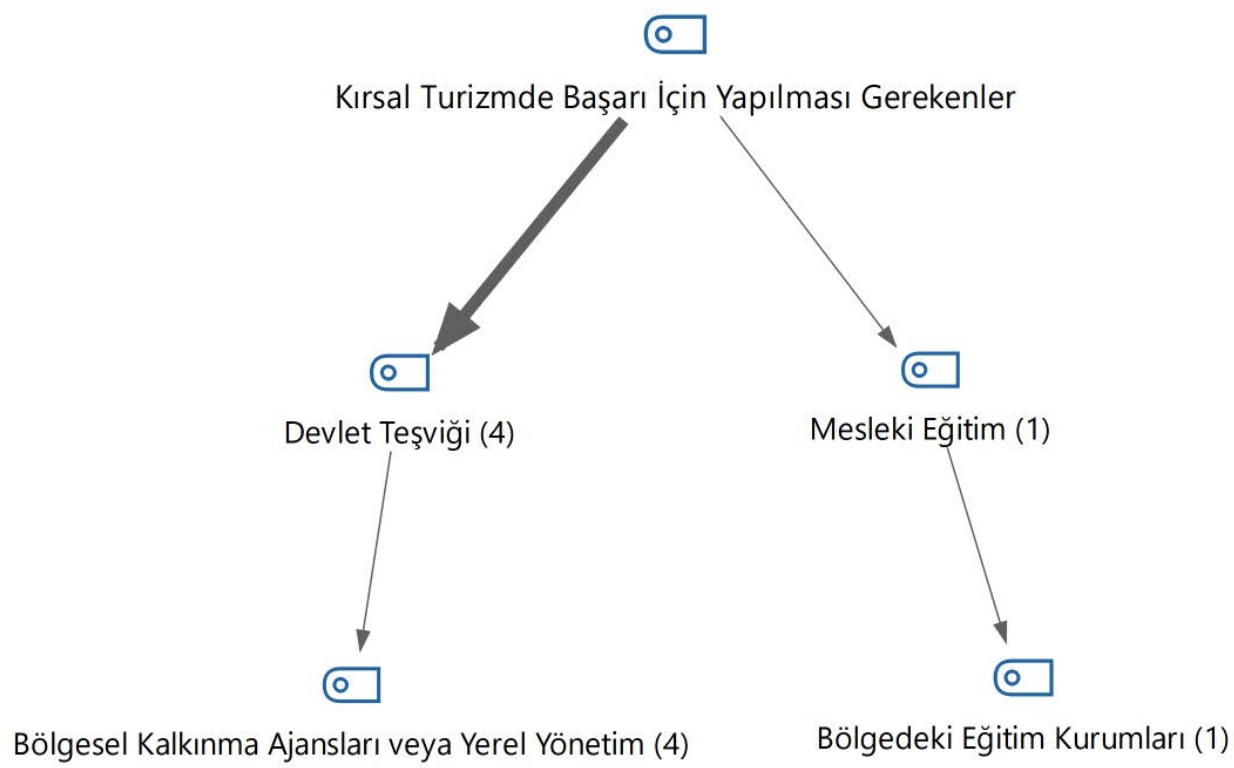

Şekil 9. Kırsal Turizmin Uygulanabilmesi İçin Ön Görülere Dair Bulgular.

Katılımcılar kırsal turizmde başarı için iki ana başlığa odaklanmıştır. Bunlar; eğitim ve devlet teşvikidir. Eğitimin başarı için kritik bir öneme sahip olduğunu ifade eden katılımcı düşüncelerini şu şekilde ifade etmiştir:

"Yöremizde kırsal turizm uygulanabilir ise gençlerin turizm ile ilgili eğitimlere ihtiyacı olacaktır. Bunun için gerekli desteği almamız gereklidir."

Devlet teşvikinin en önemli adım olacağını belirten katılımcıların düşünceleri ise şunlardır:

"Bölgede kırsal turizm konaklama alanlarının restorasyonları ve altyapılarının yenilenmesi için devletten maddi destek gereklidir." 


\section{Milli Park Sınırları İçerisinde Köylerin Kırsal Turizmin Uygulanabilmesi İçin Yerel Yönetim Beklentilerine Dair Bulgular}

Ilgaz Dağı Milli Parkı sınırları içerisinde yer alan köy muhtarlarına "Kırsal turizmin yapılması için yerel yönetimlerden beklentileriniz nelerdir?" sorusu sorulmuştur. Kırsal turizmin uygulanabilmesi için yerel yönetim beklentilerine dair değerlendirmeler maddi teşvik, ulaşım altyapısı oluşturma ve bölgenin reklamının yapılması başlıklarında değerlendirilmiştir. Tüm bu görüşlere istinaden analiz sonucunda, Ilgaz Dağı Milli Parkı sınırları içerisinde yer alan muhtarların kırsal turizmin yörede uygulanabilmesi için yerel yönetimlerden beklentilerine dair görüşler, "mali kaynak", "ulaşım ă̆ı" ve "reklam ve tanıtım" faaliyetleri temaları altında birleştirilmiştir. Şekil 10'da katılımcıların, kırsal turizmin yörede uygulanabilmesi yerel yönetim beklentilerine dair bulgular ve temalandırma gösterilmektedir.

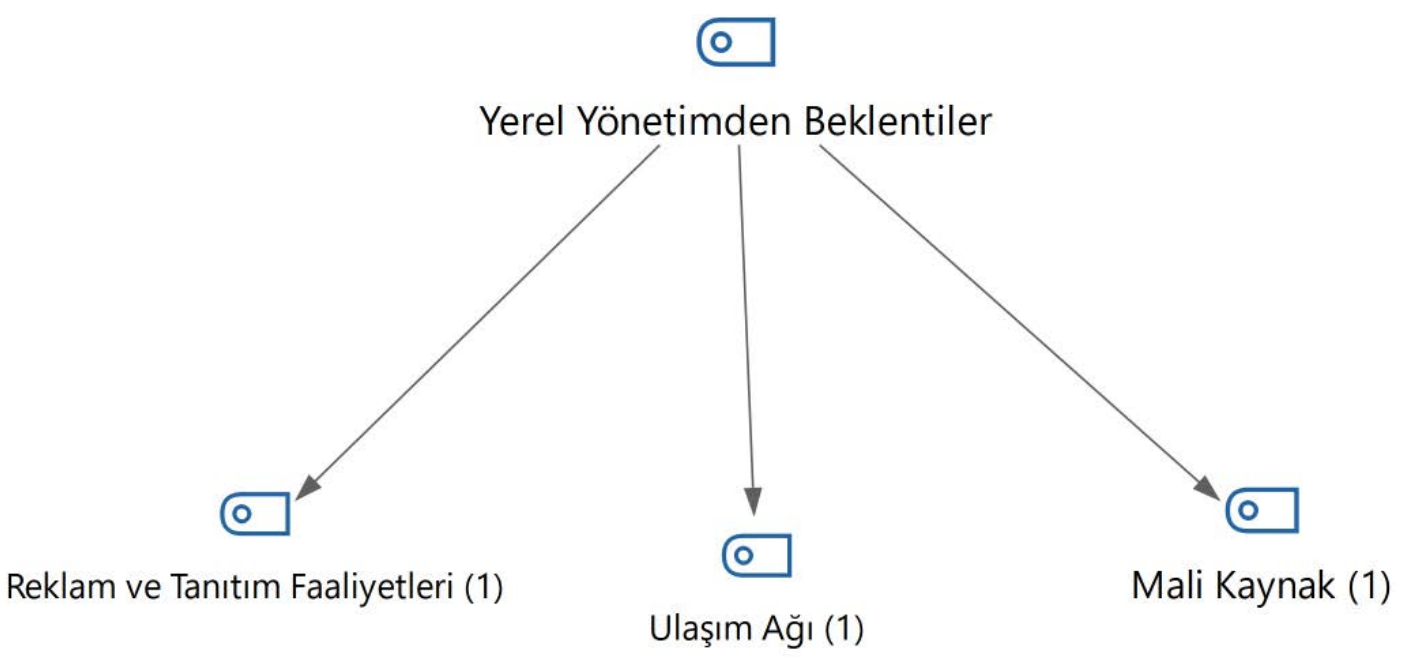

Şekil 10. Köylerin Kırsal Turizmin Uygulanabilmesi İçin Yerel Yönetim Beklentilerine Dair Bulgular.

\section{Milli Park Sınırları İçerisinde Köylerin Kırsal Turizmin Uygulanabilmesi Halinde Tersine Göç Başlatabilmesi Görüşlerine Dair Bulgular}

Ilgaz Dağı Milli Parkı sınırları içerisinde yer alan köy muhtarlarına "Kırsal turizmin yörenizde tersine göçü başlatacağını düşünüyor musunuz?" sorusu sorulmuştur. Kırsal turizmin tersine göç başlatması ile katılımcılar tarafından bölgede istihdam artışı ve köyde kalan gençler ile kültürel faaliyetlerin devamlılığı olacağı değerlendirilmiştir. Tüm bu görüşlere istinaden analiz sonucunda, Ilgaz Dağı Milli Parkı sınırları içerisinde yer alan muhtarların kırsal turizmin yörede uygulanabilmesi halinde tersine göç değerlendirmeleri "istihdam artışı" ve "kültürel bütünlük" temaları altında birleştirilmiştir. Şekil 11'de katılımcıların, kırsal turizmin yörede uygulanabilmesi halinde tersine göç değerlendirmelerine dair bulgular ve temalandırma gösterilmektedir. 


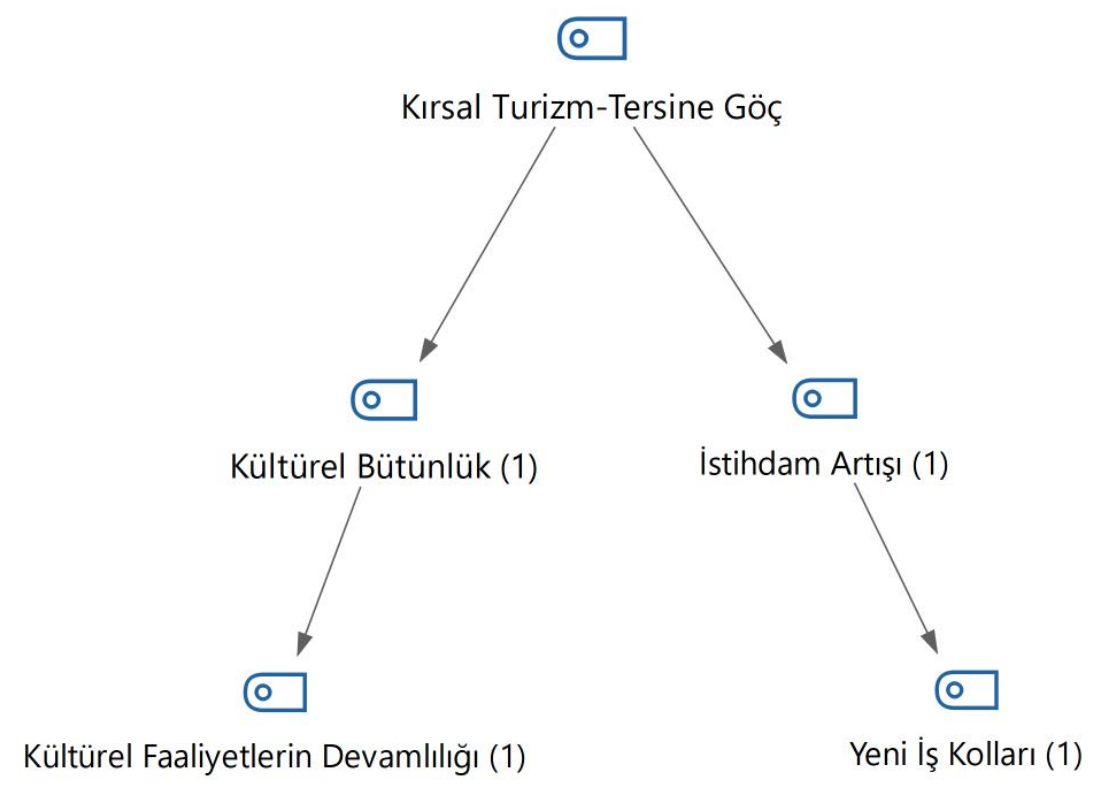

Şekil 11. Kırsal Turizmin Uygulanabilmesi Halinde Tersine Göç Başlatabilmesi Görüşlerine Dair Bulgular.

Kırsal turizm faaliyetleri ile tersine göçün olumlu anlamda etkilenebileceğini belirten katılımcılar yeni iş fırsatları için düşüncelerini şu şekilde yansıtmışlardır:

"Yöremizde turizm faaliyetlerinin artışı ile yörede yaşayan halkın şehre göçü azalarak, daha önce göç etmiş nüfusun turizm amaçlı geri dönüşü olacağı görüşündeyim."

\section{Milli Park Sınırları İçerisinde Köylerde Kırsal Turizmin Uygulanabilmesi Halinde Köyde Yaşamını Sürdürmeyen Fakat Destek Olabilecek Bireylerin Değerlendirilmesine Dair Bulgular}

Ilgaz Dağı Milli Parkı sınırları içerisinde yer alan köy muhtarlarına kırsal turizmin uygulanabilmesi halinde köylerde yaşamını sürdürmeyen fakat destek olabilecek bireylerin değerlendirilmesine ilişkin "Köyünüzde yaşamayan ancak destek olabilecek insanlar var mı?" sorusu sorulmuştur. Kırsal turizm faaliyetleri için bölgeden ayrılan kişilerin bölgenin gönüllü olarak tanıtımını yaparak ilgi uyandıracaklarını ve ekonomik özgürlüklerine kavuşmuş bireylerin işletme açabileceklerini değerlendirmişlerdir. Tüm bu görüşlere istinaden analiz sonucunda, Ilgaz Dağı Milli Parkı sınırları içerisinde yer alan muhtarların kırsal turizmin yörede uygulanabilmesi halinde köyde yaşamını sürdürmeyen bireylerin destek öngörüsü ve değerlendirmeleri "tanıtım desteği" ve "ekonomik fayda" temaları altında birleştirilmiştir. Şekil 12'de katılımcıların, kırsal turizmin yörede uygulanabilmesi halinde köyde yaşamını sürdürmeyen fakat destek olabilecek bireylerin değerlendirilmesine ilişkin bulgular ve temalandırma gösterilmektedir. 


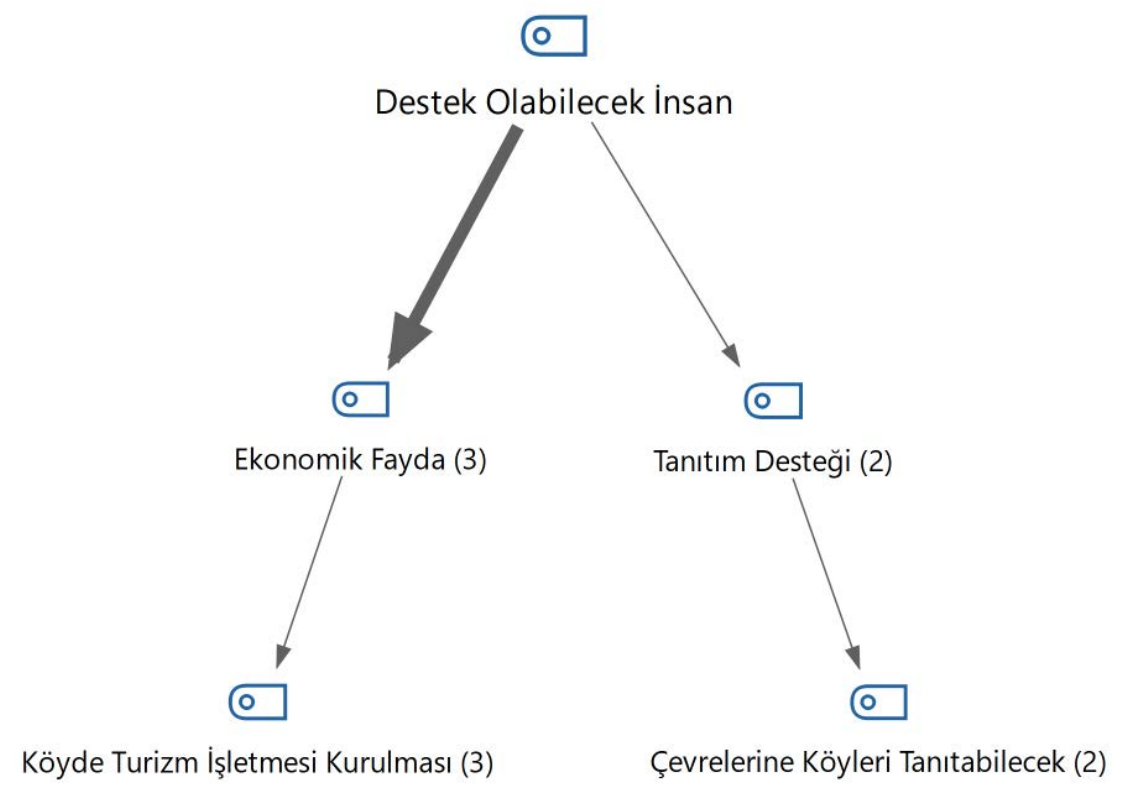

Şekil 12. Kırsal Turizmin Uygulanabilmesi Halinde Köyde Yaşamını Sürdürmeyen Fakat Destek Olabilecek Bireylerin Değerlendirilmesine Dair Bulgular.

Katılımcılar, kırsal turizm faaliyetlerinin gerçekleştirilebilmesi için köyde yaşamayan ve köyden daha önce ayrılan kişileri tanıtıma destek verebilecek kişiler olarak görmektedir.

Katılımcların görüşlerine istinaden Ilgaz Dağı'nın kırsal turizm potansiyelini aşağıdaki gibidir.

Özellikle kış aylarında kayak ve kış sporları amacıyla tercih edilen Ilgaz Dağı Milli Parkı, son yıllarda toplantı ve sempozyum aktiviteleri için de tercih edilen bir lokasyon haline dönüşmüştür. Önceliği çevreyi tanımak, yürüyüş faaliyetleri gerçekleştirmek ve dinlenmek olan ziyaretçiler ise genellikle İlkbahar, Yaz ve Sonbaharı mevsimlerinde ziyaret etmektedirler.

Bu bağlamda Milli park içerisinde yer alan mevcut ve potansiyel turizm faaliyetleri aşağıdaki gibidir.

Kuş Gözlemciliği: Ilgaz Dağları Milli Parkı özellikle sakallı akbaba, kızıl akbaba ve küçük kartal kuş türleri ile önemli kuş bölgesi konumu kazanmaktadır (Çankırı İl Kültür ve Turizm Müdürlüğü, 2007).

Dağ ve Kış Turizmi: Tırmanış, yürüyüş, piknik, kış sporları gibi faaliyetlere olanak sağlayan, 1800 m rakım ile Ilgaz Dağı, kış sporları imkanlarının yanı sıra doğal çekicilikleri ile de ziyaretçi çekmektedir. T.C. Çankırı Valiliği tarafından Kadınçayırı Mevkiinde "Yıldıztepe Dağ Sporları ve Turizm Merkezi Projesi" geliştirilerek, 1 Eylül 2005 tarihli Resmi Gazetede yayınlanan 2005/9280 sayılı Bakanlar Kurulu Kararı ile Çankırı-Ilgaz-Kadınçayırı-Yıldıztepe "Turizm Merkezi" ilan edilmiştir.

Av Turizmi: Ilgaz Dağı Milli Parkı birçok ağaç çeşidi ve endemik bitki türünü barındırmaktadır. Bunlar arasında; sarıçam (Pinus sylvestris), göknar (Abies sp.), thlamur (Tilia sp.), fındık (Corylus sp.), dağ kavağı (Populus tremula) ve meşe (Quercus sp.) bulunmaktadır. Orman Bakanlığı Merkez Av Komisyonu kararlarına göre bölgede av faaliyetleri de gerçekleştirilebilmektedir. Bölgedeki av hayvanları arasında tavşan, tilki, yaban domuzu, keklik, bıldırcın, yaban ördeği, kurt ve çakal bulunmaktadır (Anonim, 2002). Ayrıca bölgede bulunan göl ve göletlerde olta balıkçılığı da yapılmaktadır. Alabalık, aynalı sazan, levrek, yayın, tatlı su kefali ve çay balığı gibi balık çeşitleri bulunmaktadır (T.C. Çankırı Valiliği, 2005). Ayrıca Baldıran Vadisi'nde 15 Haziran 
- 15 Eylül tarihleri arasında ziyaretçilere açık olan alabalık üretme istasyonu ve avlanma göletleri bulunmaktadır (Kastamonu İl Kültür ve Turizm Müdürlüğü, 2019)

Yayla Turizmi: Bölgenin 20 kilometre yakınında ve Çankırı iline 70 kilometre uzaklıkta Kırkpınar Yaylası bulunmaktadır. Ilgaz İlçesi sınırlarında yer alan yayla $1654 \mathrm{~m}$ rakıma sahiptir. Yaylada 32 tane yayla evi ve gölet bulunmaktadır. Görsellik açısından da oldukça zengin olan yayla Karaçam (Pinus nigra), sarıçam (Pinus sylvestris) ve göknar (Abies sp.) ağaçları ile kaplıdır (T.C. Çankırı Valiliği, 2005). Bölgede yapılabilecek aktiviteler arasında piknik, kamping, atlı veya yaya doğa yürüyüşleri, karavan ve sportif olta balıkçlığ gibi aktiviteler bulunmaktadır. Yaylaya 2 kilometre mesafede Serçeler ve Bozan yaylaları yer almaktadır. Bu yaylalar da benzer özellikleri barındırmaktadır.

Yemek Kültürü:: Yemek kültürü, yörenin kendi değerlerini yansıtan önemli bir etmendir. Düğün ve iftar yemekleri bunlara örnek verilebilir. Ilgaz dügünlerinde ikram olarak keşkek, güveç ve helva tercih edilir. Keşkek, bunların arasında en meşhur olan yöresel yemektir. Diğer meşhur yöresel yemekler arasında ise Perişka, cızlama ve pıhtı aşı bulunmaktadır. Ayrıca, bölgede çeltik ekiminin yaygın olması sonucunda pirinç pilavının da ayrı bir önemi vardır (Balcı, Dağlar ve Gümüşoğlu, 2005: 82; Çakırsipahi, 2002: 78-79).

Çalışma bulguları köylerde öne çıkan turizm çeşitlerinin kuş gözlemciliği, av turizmi, dağ ve kış turizmi, yayla turizmi ve yöresel yemeklerin sunulduğu gastronomi turizmi olduğunu göstermektedir. Bulgular Ilgaz Dağı Milli Parkı sınırlarında yer alan köylerin kırsal turizm için uygun koşullar teşkil ettiğini desteklemektedir. Buna karşın bölgenin potansiyelinin arttırılabilmesi için mali kaynak, tanıtım, altyapı ve ulaşım desteğinin sağlanması gerektiği anlaşılmaktadır.

\section{SONUÇ}

Kırsal turizm, kırsal alanda ikamet eden bireyler ile ziyaretçilerin, birbirleriyle ve doğal çevreyle etkileşimde bulunduğu bir turizm türüdür. Ayrıca, yoğun iş hayatı ve tekdüze bir hayat yaşayan şehir insanına farklı bakış açıları katarak, kültür yelpazelerini geliştirmelerine, yerel kültürü deneyimlemelerine, doğal bir atmosferde, doğal beslenerek vakit geçirebilmelerine, hem de insanoğlunun varoluş kaynaklı doğaya olan özleminin giderilmesine destek olan bir turizm türüdür. Yerel halkın örgütlenerek, çevre ve diğer konularda bilinçlendirilmesi ve gerekli donanımların kendilerine sağlanması ve mesleki eğitimlerden verilmesi halinde, kırsal turizm sürdürülebilir hale dönüşecektir. Nitekim doğaya ve insana en uygun turizm aktivitelerinden biri olan kırsal turizm, geniş halk kitleleri tarafından benimsenecektir.

Çalışmada ele alınan Ilgaz Dağı Milli Parkı'nın, kırsal turizm potansiyelini belirlemeye yönelik Milli Park sınırları dâhilinde görev alan 15 köy muhtarından, 12 köy muhtarı ile odak grup görüşmesi yapılarak mevcut ve potansiyele yönelik analizler yapılmıştır. Araştırma alanı olarak seçilmiş yörede kırsal turizm faaliyetlerinin köyün kültürel yapısına nasıl etki edebileceği yerel halkın bakış açısıyla değerlendirilmeye çalışılmışır. Çalışmada katılımcılara yöneltilen sorulardan 22 adet tema belirlenmiştir. Bu temalar; ekonomik fayda, istihdam artışı, kültürel etkileşim, kültürel etkinlikler, geleneksel el sanatları, kamp ve doğa sporları, dağ ve kış turizmi, yayla turizmi, av turizmi, binicilik, doğal güzellikler, kültürel çekicilikler, istihdam artışı, sürdürülebilir turizm gelişimi, kültürel yozlaşma, taşıma kapasitesinin aşılması, devlet teşviki, mesleki eğitim, mali kaynak, ulaşım ağı, reklam ve tanıtım faaliyetleri, kültürel bütünlük, olarak belirlenmiştir.

Köylerde ev pansiyonculuğuna uygun evler olsa da turistik amaçla kullanılması için onarım görmesi gerektiği ve bunun için devlet desteğine ihtiyaç duyulduğu görülmüştür. Özellikle ana 
caddeye yakın olan köylerde yaşayan köylülerin yaptıkları ürünleri satışa sunmaları için bir alan tahsis edilmesi önerilmiştir. Gelecek olan turistlerle yerel halkın aynı evde kalacak olmasının vereceği huzursuzluğun gelir elde ettikçe düzeleceği ancak kırsal turizm aktiviteleri başlamadan özellikle psikolojik hazırlık için mutlaka eğitim verilmesi gerektiği önerisi geliştirilmiştir. Köylerdeki kırsal turizmin önündeki en büyük kısıt genç nüfus istihdamı problemidir. Köylerde yaz kış yaşayan en genç nüfusun 50-55 yaş aralığında olduğu, evlere onarım yapılsa da yeterli istihdamın olmadığı sonucuna ulaşılmıştır.

Kastamonu ilinin kırsal turizm potansiyeli birçok çalışmada değinilmiş ve potansiyel değeri vurgulanmıştır. Şen ve Erkan Buğday (2015) çalışmalarında Kastamonu ilinde iki milli park, üç tabiat parkı, dört tabiat anıtı, iki muhafaza ormanı, 22 gen koruma ormanı, dört yaban hayatı geliştirme sahası, iki tohum bahçesi, yedi tohum meşceresi ve 19 mesire alanı bulunduğunu ifade etmişlerdir. Oktay, İşlek ve Yaşar'ın çalışmasında (2016) çalışmalarında Kastamonu'nun doğa turizmi açısından Doğu Karadeniz kadar başarılı olamadığı, turizm imajının ve bölgesel kaynakların geliştirilmesi gerektiği, personelin nitelik ve niceliksel açıdan eksik bulunduğu sonuçlarına ulaşılmıştır. Zengin, Koç ve Ulama (2019) çalışmalarında da benzer sonuçlara ek olarak yerel halkta turizm bilinci oluşturulamadığı gözlemlenmiştir. Akkuş ve Akkuş (2019) çalışmalarında Kastamonu ilçelerinin arz kaynakları envanterini çıkarmışlardır. İlin öne çıkan çekicilik potansiyellerinin tabiat turizmi alt türleri ve doğa sporları oldukları belirtilmiştir. Bu çalışmalar da Kastamonu ilinin doğal güzelliklerinin oldukça zengin olduğunu desteklemekte ve çalışmada elde edilen bulgularla paralellik göstermektedir. Kastamonu ilinin turizm potansiyelinin ortaya çıkarılmasında benzer şekilde yerel yönetim desteği, tanıtım ihtiyacı ve maddi olanaksızlıklar çalışma sonuçlarını desteklemektedir. Ayrıca Küre ve Ilgaz Dağları'na yönelik çalışmalar da mevcuttur.

Öztürk (2005), Açıksöz, Görmüş ve Karadeniz (2010) çalışmasında Küre Dağları Milli Parkı'nın kanyoning, trekking, dağcllık, mağara, rafting, kampçılık, fotosafari, olta balıkçılığı ve yaban hayatı izleme gibi etkinlikler için oldukça uygun olduğunu belirtmiştir. Çalışma sonuçları Küre Dağları Milli Parkı'nı ekoturizm için önemli bir alan olarak değerlendirmektedir.

Yeşiltaş, Çeken ve Öztürk (2009) çalışmada Kastamonu ilinin Daday, Araç, Azdavay-Pınarbaşı, Tosya ve Küre ilçelerinin yayla turizmi açısından, Ilgaz dağının da dağcılık, av turizmi ve trekking açısından uygun olduğunu belirtmiştir. Göktuğ ve Arpa (2015) çalışmalarında doğa turizmi açısından dağ yürüyüşü (trekking), kış turizmi, dağ bisikleti, bitki inceleme gezileri, fauna gözlemi, foto safari etkinlikleri ve kamp etkinlikleri gibi faaliyetlerin yapılabileceği ifade etmişlerdir. Akkuş (2019) çalışmasında Ilgaz Dağı'nı kış turizmi için önemli bir çekicilik noktası olarak belirtmiştir.

Literatür ve çalışma sonuçlarına göre Ilgaz Dağı Milli Parkı'nda öne çıkan turizm faaliyetleri kuş gözlemciliği, dağ ve kış turizmi, av turizmi, yayla turizmi ve bölgenin yöresel yemeklerinin sunulduğu gastronomi turizmidir. Çalışma sonuçları literatür ile paralellik göstermekle birlikte, bu çalışmada farklı olarak bazı sonuçlar elde edilmiştir. Köy muhtarlarının turizm potansiyelinin ve sunulabilecek turizm çeşitlerinin farkında olmaları ile birlikte özellikle bazı olumsuz noktaların üzerinde durdukları görülmektedir. Diğer çalışmalardan farklı olarak muhtarların taşıma kapasitesi ve kültürel yozlaşma gibi kavramlara, bölgenin doğasına gelebilecek zarara ve sosyo-kültürel düzeyi koruma bilincine hakim oldukları gözlemlenmektedir. Köydeki nüfusun yaşlı bir nüfus olduğunu ve daha önce bölgede yaşayıp göç edenlerin potansiyel yatırımcı ve tanıtıcı olarak görülmesi gerektiğini belirtmişlerdir. Bu noktada tersine göçün önemini vurgulamışlardır. Benzer şekilde bölgede artabilecek turizm hareketlerinin de olası getirilerinin farkında oldukları gözlemlenmiştir. Kırsal turizmde başarı için ise devlet teşviği ile beraber eğitim planlamasının da yapılması gerektiği belirtilmiştir. 
Özellikle ekonomik kaynak sağlayacağı ön görüşü nedeniyle kırsal turizme bakış açıları olumlu olmakla birlikte kültürel etkiler konusunda olumlu - olumsuz değerlendirmelere ulaşılmıştır. Bu bağlamda; kırsal nüfusun yörede kalıcı olması ve söz konusu alanda çalışanların, yerel yönetim tarafında mesleki eğitim ve kırsal bölgelere daha kolay ulaşım için servis ağları beklentileri mevcuttur. Ulusal ölçekte ise devlet teşviki ve yöreye has yapı onarımı için kaynak ihtiyacının karşılanması gerekmektedir.

$\mathrm{Bu}$ çalışma Kastamonu İli Ilgaz Dağı Milli Parkı sınırları içirişinde gerçekleştirilmiştir. Kastamonu ili için yapılan doğa turizmi ve kırsal turizm çalışmaları mevcut olmakla birlikte, olası problemlerin devam ettiği gözlemlenmektedir. Bu noktada turizmde yeterli potansiyele ulaşılmadığı baz alındığında yerel ve ulusal farkındalığın oluşturulamadığından söz edilebilir. Bu noktada doğa turizmi bilincini oluşturmak ve Kastamonu da dâhil olmak üzere Türkiye' deki doğa turizmi potansiyelini arttırabilmek için çalışmaların arttırılmasına ihtiyaç vardır. Farklı parametreler ve farklı bileşenler ölçülerek bu değerlendirme gerçekleştirilebilir. Çalışma kapsamında köy yönetiminden muhtarlar değerlendirilmiştir. Bu bağlamda hem tüketici ve hem de yönetici bazlı çalışmalar ele alınabilir.

\section{KAYNAKÇA}

Açıksöz, S., Görmüş, S. and Karadeniz, N. (2010). Determination of ecotourism potential in national parks: Kure mountains national park, Kastamonu-Bartin, Turkey. African Journal of Agricultural Research, 5(8), 589-599.

Akkuş, G. ve Akkuş, Ç. (2019). Kastamonu İlçeleri Temel Turistik Arz Kaynakları Envanteri: Tabiat Turizmi Alt Türleri ve Doğa Sporları, International Journal of Turkic World Tourism Studies, $4(2), 146-164$.

Akkuş, G. (2019). Ilgaz dağında kış turizm talebi ve gelişimi. Çankırı Karatekin Üniversitesi İ̈BF Dergisi. $9(1), 1-27$.

Albayrak, A. (2013). Alternatif Turizm. Ankara: Detay Yayıncllı.

Avcıkurt, C. ve Köroğlu, Ö. (2011). Kırsal Turizm. N. Hacıŏlu ve C. Avcıkurt İçinde, Turistik Ürün Çeşitlendirmesi (S. 67). Ankara: Nobel Yayıncılık.

Balcı, S., Dağlar, H. ve Gümüşoğlu, Z. (2005). Geçmişten Bugüne Çankırı'da Sofra Adabı ve Yemek Kültürü. Geçmişten Geleceğe Çankırı, Çankırı Valiliği III. Çankırı Kültürü̈ Bilgi Şöleni Bildirileri (28-29 Eylül 2005), 81-91.

Bouchon, F. and Rawat, K. (2016). Rural Areas of ASEAN and Tourism Services, a Field for Innovative Solutions. Procedia-Social and Behavioral Sciences (224), 44-51.

Belletti, G. (2010). Ruralità e turismo. Agriregionieuropa, 20, 11-13.

Belletti, G. and Berti, G. (2011). Turismo, ruralità e sostenibilità attraverso l'analisi delle configurazioni turistiche. Aree rurali e configurazioni turistiche: differenziazione e sentieri di sviluppo in Toscana, 21-62.

Çeken, H., Karadağ, L. ve Dalgın, T. (2007). Kırsal Kalkınmada Yeni Bir Yaklaşım Kırsal Turizm ve Türkiye'ye Yönelik Teorik Bir Çalışma. Artvin Çoruh Üniversitesi Orman Fakültesi Dergisi, 7, 114.

Çankırı Valiliği (2006). Çankırı İl Haritası. http://www.cankiri.gov.tr (Erişim Tarihi: 01/06/2019). 
Doğa Koruma ve Milli Parklar Genel Müdürlüğü (2002). http://ilgazdagi.tabiat.gov.tr/ (Erişim Tarihi: 05/06/2019).

Göktuğ, T. H. ve Arpa, N. Y. (2015). Korunan alanlar yönetimi bağlamında kayak merkezlerinin fiziksel ve sosyal taşıma kapasitelerinin analizi: Ilgaz Dağı Milli Parkı, Ilgaz Kış Sporları Turizm Merkezi. Kastamonu Üniversitesi Orman Fakültesi Dergisi, 15(1), 104-119.

Hall, C. M. and Jenkins, J. (1998). The policy dimensions of rural tourism and recreation. In R. Butler, C. M. Hall, and J. Jenkins (Eds.), Tourism and recreation in rural areas (pp. 19-42). Chichester: Wiley.

https://www.kastamonu.bel.tr/v2/portfolio/ilgaz-dagi-milli-parki-ve-kayak-merkezi/ (Erişim tarihi: 07/04/2019).

Kastamonu İl Kültür ve Turizm Müdürlüğü. (2019) Milli Parklar ve Korunan Alanlar. https://kastamonu.ktb.gov.tr/TR-63883/milli-parklar-ve-korunan-alanlar.html (Erişim Tarihi: 05/05/2019).

Kuter, N. (2008). Ilgaz Dağı Milli Parkı'nın Orman Peyzajı ve Estetiği Açısından Değerlendirilmesi. Isparta, Süleyman Demirel Üniversitesi Orman Fakültesi Dergisi, 1: 36-47.

Lane (1993), Rural Tourism: A Bibliography, OECD, Parigi. (1994), Tourism Strategies and Rural Development, OECD, Parigi.

Lane, B. (1994). What is Rural Tourism, Journal of Sustainable Tourism, 2(1), 7-21.

Lee, S. W. and Kim, H. J. (2010). Agricultural transition and rural tourism in Korea: experiences of the last forty years. In G. Thapa, P. Viswanathan, J. Routray and M. Ahmad (Eds.), Agricultural transition in Asia (pp. 37-64). Bangkok: Asian Institute of Technology.

M.S. Dann (1999), Theoretical Issues for Tourism's Future Development: Identifying the Agenda, in D. G. Pearce, R.W. Butler (Eds.), Contemporary Issues in Tourism Development, Routledge, Londra, pp. 13-30

OECD (1994). Tourism Policy and International Tourism in OECD Countries 1991-1992. Paris: Organisation for Economic Co-Operation and Development

Oktay, K., İşlek, E. ve Yaşar, U. (2016). Kastamonu'da Doğa Turizmi Potansiyelinin Değerlendirilmesi. Türk Bilimsel Derlemeler Dergisi, 9(2), 47-54.

Özgürel, G. (2015). Tunceli İli Kırsal Turizm Potansiyeli ve Yerel Halkın Turizme Yönelik Bakışları. International Journal of Social and Economic Sciences, 5(2), 64-76.

Öztürk, S. (2005). Kastamonu-Bartın Küre Dağları Milli Parkı'nın rekreasyonel kaynak değerlerinin irdelenmesi. Süleyman Demirel Üniversitesi Orman Fakültesi Dergisi, A (2), 138-148.

Şen, G. ve Erkan Buğday, S. (2015). Kastamonu ilinde çeşitli statülerde koruma ve kullanma amaçlı belirlenmiş alanlar. Kastamonu Üniversitesi Orman Fakültesi Dergisi, 15(2), 214-230.

Tarım ve Köy İşleri Bakanlığı (2003) II. Tarım Şurası, Kırsal Kalkınma Politikaları Komisyon Raporu: 8. Ankara: Tarım ve Köy İşleri Bakanlığı.

Uçar, M., Çeken, H. ve Ökten, Ş. (2010). Kırsal Turizm ve Kırsal Kalkınma (Fethiye Örneği). Ankara: Detay Yayıncilik.

White, M. and Marsh , E. (2006). Content Analysis: A Flexible Methodology. Library Trends, 55(1), 22-45. 
Yemenoğlu, E., Dalgın, T. ve Çeken, H. (2013). Geleneksel Festivallerin Kırsal Turizm Üzerindeki Etkileri: Denizli-Honaz Kiraz Festivali Örneği. Uluslararası Sosyal ve Ekonomik Bilimler Dergisi, 3 (1), 16-21.

Yeşiltaş, M., Çeken, H. ve Öztürk, İ. (2009). Karadeniz bölgesindeki turizm olanaklarının SWOT analizi ile değerlendirilmesi. Adıyaman Üniversitesi Sosyal Bilimler Enstitüsü Dergisi, 2(3), 250-269.

T.C. Çankırı Valiliği (2005). http://www.cankiri.gov.tr/cankiri-kultur-envanteri (Erişim Tarihi:10/06/2019).

T.C. Ilgaz Kaymakamlı̆̆ı. (2017). http://www.ilgaz.gov.tr/ilcemiz (Erişim Tarihi: 10/04/2019).

$\begin{array}{llll}\text { Türk Dil Kurumu, (T.D.K.), } & \end{array}$ http://www.tdk.gov.tr/index.php?option=com_gts\&arama=gts\&guid=TDK.GTS.5da34b836eb76 3.33061796 (Erişim tarihi: 05/04/2019).

Zengin, B., Koç, D. ve Ulama, Ş. (2019). Kastamonu İlinin Doğa Turizmi Potansiyelinin Alternatif Turizm Kapsamında Değerlendirilmesi. Safran Kültür ve Turizm Araştırmaları Dergisi, 2(2), 251274. 